\title{
OPEN Enhancement of the nutritional value of fermented corn stover as ruminant feed using the fungi Pleurotus spp.
}

\author{
Yuqiong Wang ${ }^{1}$, Yang Luo ${ }^{2}$, Lilong Luo ${ }^{1}$, Hang Zhang ${ }^{1}$, Yangci Liao ${ }^{3 凶}$ \& Changlong Gou ${ }^{1 \bowtie}$
}

Four Pleurotus spp. fungi (P. diamor, $P$. eryngii, $P$. sajor-caju, $P$. citrinopileatus) were compared for their potential to improve nutritional value of corn stover as ruminant feed. Corn stover was inoculated with the fungi under solid-state conditions and their results showed that $P$. sajor-caju and $P$. eryngii were better than the other two species of Pleurotus with respect to decreasing the acid detergent lignin (ADL) (8.99 vs 9.88 vs 10.16 vs 10.46$)$. In contrast, $P$. eryngii had lower ability to degrade cellulose (13.38\%). Corn stover treated with $P$. citrinopileatus had the highest crude protein (CP) content (7.65\%), whereas treatment with $P$. sajor-caju resulted in the highest increase in essential amino acids (55.11\%). Although fungal pre-treatment of lignocellulosic biomass does not always result in high-quality feed, overall, $P$. eryngii and $P$. sajor-caju improved the nutritive value of corn stover as a ruminant feed.

Straw, one of the most abundant agricultural wastes in China, is commonly used as a roughage source in ruminant diets. However, its high content of lignocellulosic biomass and low content of both protein and energy ${ }^{1}$ limit its value as a ruminant feedstuff. To improve nutritional value, various methods have been studied, including physical, chemical and biological treatments ${ }^{2}$. Physical methods involving extreme temperature or pressure improve palatability, but do not enhance nutritive value. Chemicals can be used to destroy cell wall structures and improve nutritive value of crop residues ${ }^{3}$. Although a chemical method is easy and very efficient to apply and it may result in compounds that are unsuitable for animal feed and hazardous for the environment. Biological methods, including using a fungus to degrade lignocellulosic biomass and support fungus growth, are generally more environmentally friendly than chemical pretreatment ${ }^{4}$. Furthermore, following fungal growth, the proteinaceous fungal mycelium also contributes to the nutritive value of solid-state fermentation materials ${ }^{5}$. Consequently, this treatment method can increase both digestability and protein content of straw as a source of animal feed ${ }^{6}$.

White rot fungi (basidiomycetous) produce various extracellular ligninolytic enzymes that delignify and break down the recalcitrant component of plant cell walls ${ }^{4}$. Lignin-modifying enzymes are crucial for degradation of lignin compounds for producing feed suitable for ruminants. Fungal strains vary in their ability to digest a substrate and grow, depending on substrate nutrient composition and fermentation conditions ${ }^{7}$. Thus, it is important to identify appropriate combinations of fungal strain and straw to optimize digestion and increase the subsequent nutritive value. The nutritional value of fermentation substrate was evaluated comprehensively, which was beneficial to promoting the straw feed process. For instance, amino acid composition and vitamin contents are important factors when evaluating feed quality. Furthermore, detailed nutritional composition of feed is important when creating a balanced ration to increase productivity and reduce production costs.

Pleurotus spp. is a common decomposer of agricultural residues and easy to artificially cultivate. Four representative Pleurotus species, namely Pleurotus djamor, Pleurotus eryngii, Pleurotus sajor-caju, Pleurotus citrinopileatus were selected due to their nontoxicity and low cost, and identify the one that resulted in the best nutrient values of corn stover (CS). For developing a solid fermentation process for the conversion of corn stover into more nutritive animal feed using Pleurotus spp.

${ }^{1}$ College of Animal Science and Technology, Inner Mongolia University for Nationalities, Tongliao, China. ${ }^{2}$ Hunan Institute of Animal and Veterinary Science, Changsha, China. ${ }^{3}$ Institute of Pratacultural, Tibet Academy of Agricultural and Animal Husbandry Sciences, Lhasa, China. ${ }^{\square}$ email: janney520120@qq.com; gouchanglong1988@163.com 


\section{Materials and methods}

Fungal strains and spawn preparation. Four white rot fungi, P. djamor CGMCC 5.600, P. eryngii CGMCC 5.732, P. sajor-caju CGMCC 5.592 and P. citrinopileatus CGMCC 5.244 were used. They were procured from the China General Microbiological Culture Collection Center (CGMCC) in Beijing, China, grown in potato dextrose agar medium (PDA) (potato $200 \mathrm{~g}$; peptone, $10 \mathrm{~g}$; glucose $20 \mathrm{~g}$; and agar $18 \mathrm{~g}$; per L) and stored at $4{ }^{\circ} \mathrm{C}$. Agar plates were prepared using PDA and inoculated with a $0.5 \mathrm{~cm}^{2}$ piece of the fungus at $25^{\circ} \mathrm{C}$ for $7 \mathrm{~d}$. Four agar plugs (diameter, $8 \mathrm{~mm}$ ) of active mycelium from PDA plate was transferred aseptically into $250 \mathrm{ml}$ Erlenmeyer flasks containing $80 \mathrm{ml}$ of autoclaved potato extract dextrose broth medium (PDB) (potato $200 \mathrm{~g}$; peptone $10 \mathrm{~g}$ and glucose $20 \mathrm{~g}$; per L). The cultures were incubated at $25^{\circ} \mathrm{C}$ in rotary shakers $(150 \mathrm{rpm})$.

Experimental set-up. Corn stover (CS) was collected from the Changling Station for Grassland and Agroecology, Chinese Academy of Sciences, Jilin, China ( $\left.44^{\circ} 33^{\prime} \mathrm{N}, 123^{\circ} 31^{\prime} \mathrm{E}\right)$. The ingredients of cultivation substrate were CS (chopped to $2-3 \mathrm{~cm}$ lengths), corn meal $1 \%$, urea $1 \%$, land plaster $0.5 \%, \mathrm{~K}_{2} \mathrm{HPO}_{4} 1 \%$, vitamin mix $0.5 \%$ and minerals $0.5 \mathrm{~g} / \mathrm{kg}$ (comprised of $\mathrm{Na}=0.15, \mathrm{~K}=0.15$ and $\mathrm{Mg}=0.2)$. Cultivation substrate $(200 \mathrm{~g}$, $65 \%$ moisture) was put into an autoclavable plastic bag and sterilized at $121{ }^{\circ} \mathrm{C}$ for $1 \mathrm{~h}$ and allowed to cool at room temperature. Samples were inoculated with $10 \%$ spawn and incubated for 21 days in a climatic chamber at $25 \pm 0.5^{\circ} \mathrm{C}$ with $70-80 \%$ relative humidity. Controls were carried out in uninoculated microorganism under the same experimental conditions. Containers with inoculated CS were inoculated in triplicate.

Chemical analyses. At 21 days after inoculation, substrate samples were dried at $60{ }^{\circ} \mathrm{C}$ until they reached a constant weight and then they were analyzed to determine nutritional value. A portion of each sample was freeze-dried, stored at $-18{ }^{\circ} \mathrm{C}$ and used to determine amino acid and vitamins contents. Total weight loss was calculated as the percentage of total solids lost after pretreatment. Total nitrogen content was determined by the Kjeldahl method, with a conversion factor of 6.25. Ethyl ether extract was determined by the Soxhlet method. The ash content was determined by ashing at $550{ }^{\circ} \mathrm{C}$ in a muffle furnace for $3 \mathrm{~h}$. Neutral detergent fiber (NDF), acid detergent fiber (ADF), cellulose, hemicellulose and ADL were carried out with slightly modified method of Goering and Vansoest ${ }^{8}$ and Van Soest ${ }^{9}$. Samples (0.5-1 g) were placed into polyester mesh bags (ankom F57) and sealed. Bags and $2000 \mathrm{ml}$ of neutral detergent were put into the Semi-automatic fiber analyzer (ANKOM $200 \mathrm{i})$ at $100^{\circ} \mathrm{C}$ for $60 \mathrm{~min}$. Then, the bags were washed to neutral with distilled water, dried and weighed. Dried residue was represented as NDF. Remaining samples and $2000 \mathrm{ml}$ of acid detergent were put into the Semi-automatic fiber analyzer at $100{ }^{\circ} \mathrm{C}$ for $60 \mathrm{~min}$. Then, the bags were washed to neutral with distilled water, dried and weighed. Dried residue was represented as ADF. The loss was represented as hemicellulose. Dried residue was soaked in $72 \%(\mathrm{v} / \mathrm{v}) \mathrm{H}_{2} \mathrm{SO}_{4}$ and kept at $25^{\circ} \mathrm{C}$ for $2 \mathrm{~h}$. Thereafter, the bags were washed to neutral with distilled water, dried and weighed. The loss was represented as cellulose. The remaining samples was kept at $550{ }^{\circ} \mathrm{C}$ for $3 \mathrm{~h}$ in a tared crucible and reweighed to calculate the loss as ADL.

Amino acid content. An aliquot (0.2-0.5 g of each sample) was soaked in $10 \mathrm{ml}$ of $6 \mathrm{~N} \mathrm{HCl}$ in an autoclave at $110^{\circ} \mathrm{C}$ for $24 \mathrm{~h}$. The hydrolysate was filtered through a $0.22 \mu \mathrm{m}$ cellulose acetate membrane filter before injection into the HPLC.

Amino acid composition analysis of methyl esters was done using an HPLC system (Model 1290, Agilent Technologies, Palo Alto, CA, USA) with autosampler, a Agilent Zorbax-AAA column $(4.6 \times 150 \mathrm{~mm}, 3.5 \mu \mathrm{m})$ with a Zorbax-AAA guard column $(4.6 \times 12.5 \mathrm{~mm}, 5 \mu \mathrm{m})$ and fluorescence detector. The sample was submitted to automatic precolumn derivatization with a combination of OPA reagent for primary amino acids and FMOC secondary amino acids. Mobile phase A contained $20 \mathrm{mmol} / \mathrm{L}$ natrium aceticum at $\mathrm{pH}$ 7.2, whereas B contained $20 \%$ antrium aceticum, $40 \%$ acetonitrile, and $40 \%$ methanol at $\mathrm{pH}$ 7.2. The chromatographic column temperature was set at $40{ }^{\circ} \mathrm{C}$ with a flow rate of $1 \mathrm{ml} /$ minute.

Vitamin analyses. Vitamin B1 (thiamine), B2 (riboflavin) and B6 (pyridoxine) content were assessed using HPLC. Samples (1-5 g) were extracted with $60 \mathrm{ml}$ of extraction buffer (50 mg disodium ethylenediamine tetraacetic acid ( $\mathrm{Na}_{2}$ EDTA), $25 \mathrm{ml}$ acetic acid, $5 \mathrm{ml}$ triethylamine with deionized water added to reach a volume of $1000 \mathrm{ml}$, then $860 \mathrm{ml}$ mixed with $140 \mathrm{ml}$ methyl alcohol), supersound extraction for $20 \mathrm{~min}$ and cooled to room temperature. The sample extract was a constant volume of $100 \mathrm{ml}$. The extract was filtered through a $0.22 \mu \mathrm{m}$ cellulose acetate membrane filter before injection into the HPLC. Analysis was carried out on Agilent Zorbax SB-C18 $(4.6 \times 150 \mathrm{~mm})$ with Agilent Zorbax SB-C18 $(4.6 \times 12.5 \mathrm{~mm})$ and was conducted at an excitation wavelength of $280 \mathrm{~nm}$. Column temperature was $28^{\circ} \mathrm{C}$ Isocratic elution with a flow of $1 \mathrm{ml} / \mathrm{minute}$ were performed using a solution of methanol and Pic-A reagent $(50 \mathrm{mg}$ disodium ethylenediaminetetraacetic acid $\left(\mathrm{Na}_{2}\right.$ EDTA), $1.1 \mathrm{~g}$ sodium heptanesulfonate, $25 \mathrm{ml}$ acetic acid, $5 \mathrm{ml}$ triethylamine with deionized water volume to $1000 \mathrm{ml})$.

In vitro digestibility. In vitro digestibility (IVD) of control and treatment groups were measured according to Akthter et al. ${ }^{10}$, as described by Sharma and Arora ${ }^{11}$. Two-stage digestion included samples with fecal inoculum and acidified pepsin. Fecal inoculum was prepared by mixing fresh fecal matter ( $100 \mathrm{~g} / \mathrm{l})$ from cows in pre-warmed $\left(39^{\circ} \mathrm{C}\right.$ artificial saliva) and filtered through six layers of muslin cloth. Samples $(0.4 \mathrm{~g})$ were placed in a $70 \mathrm{ml}$ fermentation flask, with addition of $40 \mathrm{ml}$ of fecal inoculums (flushing with $\mathrm{CO}_{2}$ gas). These fermentation flasks were kept at $39^{\circ} \mathrm{C}$ for $48 \mathrm{~h}$ in a water bath. After fermentation ended, samples were filtered and dried at $65^{\circ} \mathrm{C}$ for $48 \mathrm{~h}$. Acidified pepsin $(35 \mathrm{ml})$ was added to the fermentation flasks. These fermentation flasks were kept at $39^{\circ} \mathrm{C}$ for $48 \mathrm{~h}$ in a water bath. The reaction was stopped using $100^{\circ} \mathrm{C}$ water, followed by $10^{4}$ revolutions/ 


\begin{tabular}{|c|c|c|c|c|c|c|c|}
\hline Fungi/sample & P. diamor & P. eryngii & P. sajor-caju & P. citrinopileatus & Autoclaved straw (control) & SEM & $P$ value \\
\hline $\mathrm{CP}$ & $7.11^{\mathrm{ab}}$ & $6.84^{\mathrm{b}}$ & $6.70^{\mathrm{b}}$ & $7.65^{a}$ & $4.75^{\mathrm{c}}$ & 0.208 & $<0.001$ \\
\hline Ash & $9.93^{\mathrm{a}}$ & $9.35^{\mathrm{a}}$ & $9.55^{\mathrm{a}}$ & $9.56^{\mathrm{a}}$ & $2.61^{\mathrm{b}}$ & 0.214 & $<0.001$ \\
\hline $\mathrm{EE}$ & $1.36^{\mathrm{a}}$ & $1.04^{\mathrm{b}}$ & $1.22^{\mathrm{ab}}$ & $1.23^{\mathrm{ab}}$ & $0.75^{\mathrm{c}}$ & 0.08 & 0.003 \\
\hline NDF & $63.95^{\mathrm{b}}$ & $63.64^{\mathrm{bc}}$ & $65.11^{\mathrm{b}}$ & $62.15^{c}$ & $68.76^{\mathrm{a}}$ & 0.52 & $<0.001$ \\
\hline ADF & $48.57^{\mathrm{b}}$ & $49.36^{\mathrm{b}}$ & $48.34^{\mathrm{b}}$ & $48.63^{\mathrm{b}}$ & $51.56^{\mathrm{a}}$ & 0.384 & $<0.001$ \\
\hline $\mathrm{ADL}$ & $10.46^{\mathrm{b}}$ & $9.88^{\mathrm{bc}}$ & $8.99^{c}$ & $10.16^{\mathrm{b}}$ & $12.31^{\mathrm{a}}$ & 0.315 & $<0.001$ \\
\hline Hemicellulose & $29.1^{\mathrm{bc}}$ & $29.31^{\mathrm{b}}$ & $28.69^{\mathrm{bc}}$ & $27.84^{\mathrm{c}}$ & $32.24^{\mathrm{a}}$ & 0.383 & $<0.001$ \\
\hline Cellulose & $47.55^{\mathrm{b}}$ & $48.07^{\mathrm{b}}$ & $48.35^{\mathrm{b}}$ & $46.97^{b}$ & $50.82^{\mathrm{a}}$ & 0.575 & 0.007 \\
\hline IVD \% & $40.58^{c}$ & $44.05^{\mathrm{b}}$ & $46.56^{\mathrm{a}}$ & $25.16^{\mathrm{d}}$ & $21.29^{\mathrm{e}}$ & 0.225 & $<0.001$ \\
\hline
\end{tabular}

Table 1. Chemical composition of corn stover after 21 days of incubation with various white rot fungi (Pleurotus sp.) or control. SEM: standard error of mean. ${ }^{\mathrm{a}-\mathrm{e}}$ Within a row, means without a common superscript differed $(P<0.001)$.

\begin{tabular}{|l|c|c|c|c|l|c|}
\hline Fungi/sample & P. diamor & P. eryngii & P. sajor-caju & P. citrinopileatus & SEM & P value \\
\hline DM & $21.2^{\mathrm{a}}$ & $8.41^{\mathrm{b}}$ & $19.2^{\mathrm{a}}$ & $20.63^{\mathrm{a}}$ & 0.708 & $<0.001$ \\
\hline CP & $-17.81^{\mathrm{a}}$ & $-31.66^{\mathrm{b}}$ & $-13.83^{\mathrm{a}}$ & $-27.7^{\mathrm{b}}$ & 1.75 & $<0.001$ \\
\hline NDF & $30.74^{\mathrm{a}}$ & $16.44^{\mathrm{c}}$ & $25.62^{\mathrm{b}}$ & $28.28^{\mathrm{ab}}$ & 0.946 & $<0.001$ \\
\hline ADF & $25.79^{\mathrm{a}}$ & $12.33^{\mathrm{b}}$ & $24.25^{\mathrm{a}}$ & $25.15^{\mathrm{a}}$ & 0.71 & $<0.001$ \\
\hline ADL & $33.03^{\mathrm{ab}}$ & $26.5^{\mathrm{b}}$ & $40.95^{\mathrm{a}}$ & $34.44^{\mathrm{ab}}$ & 2.542 & 0.025 \\
\hline Hemicellulose & $28.87^{\mathrm{a}}$ & $16.74^{\mathrm{b}}$ & $28.09^{\mathrm{a}}$ & $31.44^{\mathrm{a}}$ & 1.29 & $<0.001$ \\
\hline Cellulose & $26.29^{\mathrm{a}}$ & $13.38^{\mathrm{b}}$ & $23.13^{\mathrm{a}}$ & $26.62^{\mathrm{a}}$ & 1.22 & $<0.001$ \\
\hline
\end{tabular}

Table 2. Loss of nutrients (\%) from corn stover after 21 days of incubation with various white rot fungi (Pleurotus sp.) or control. SEM: standard error of mean. ${ }^{\mathrm{a}-\mathrm{b}}$ Within a row, means without a common superscript differed $(P<0.001)$.

minute for $20 \mathrm{~min}$ and then residue was filtered on a filter paper (of known weight) and dried. Weight loss in dry matter during processing was expressed as IVD.

Statistical analyses. All data were analyzed using the General Linear Model procedure (GLM), followed by Duncan's multiple range tests (SAS, 2008). Means were separated using least square means and presented with standard errors of the mean (SEM). The statistical model used for all data was:

$$
Y_{i j}=\mu+\alpha_{i}+\varepsilon_{i j}
$$

where $Y \mathrm{ij}=$ the response variable, $\mu=$ the general mean, $\alpha \mathrm{i}=$ the effect of white-rot fungi and $\varepsilon \mathrm{ij}=$ the random error. Results were considered different when $P \leq 0.05$.

\section{Results}

Chemical composition. In the present study, four white rot fungi significantly altered the chemical composition of CS compared to uninoculated CS (Table 1). Pretreatment of CS with any one of the four white-rot fungi increased CP $13.83-31.66 \%$ and either extract $(P<0.01)$, but concurrently reduced NDF, ADL, hemicellulose $(P<0.001)$, ADF and cellulose $(P<0.01)$ content of CS. Treatment with $P$. citrinopileatus resulted in the greatest increase $(P<0.05)$ in $\mathrm{CP}$ content, whereas the greatest increase in EE was in CS exposed to $P$. diamor, followed by $P$. citrinopileatus, $P$. sajor-caju and $P$. eryngii. Furthermore, all four white rot fungi caused net reductions in DM, OM, NDF, ADF, ADL, cellulose and hemicellulose (Table 2). The loss of cell wall constituents was smallest $(P<0.05)$ for $P$. eryngii and highest for $P$. diamor. Corn stover pre-treated with $P$. diamor had the greatest reduction in NDF (30.74\%) and ADF (25.79\%), whereas P. sajor-caju degraded maximum ADL (40.95\%), followed by $P$. citrinopileatus; this fungus also caused maximum degradation of hemicellulose $(31.44 \%)$ and cellulose (26.62\%). P. eryngii increased maximum CP (31.66\%) but caused the least degradation of DM (8.41\%). All fungi resulted in significantly higher IVD compared to the autoclaved CS. Incubations with P. sajor-caju resulted in the highest IVD (118.69\%) followed by P. eryngii, whereas $P$. citrinopileatus had the least change in IVD (18.18\%).

Amino acids. Amino acids are secondary metabolites of fungi and reliable indicators of nutritional value $\mathrm{e}^{12}$. There were differences among strains $(P<0.05)$ in how white-rot fungi CS affected amino acid content (Table 3). After 21 days of incubation, there were increases in content of most amino acids, expect for alanine (Ala), methionine (Met), tyrosine (Tyr). Incubation of CS with fungi increased leucine (Leu), phenylalanine (Phe), lysine (Lys) $(P<0.001)$, threonine (Thr) $(P<0.01)$ and valine $(\mathrm{Val})(P<0.05)$ compared to the control. Compared to autoclaved straw, Leu was the most abundant $(48.27,25.46,49.33$ and $54.4 \%$ in diamor, eryngii, sajor-caju, citrinopileatus, respectively). Val was the second most abundant essential amino acid, followed by Lys, Thr, Phe, 


\begin{tabular}{|l|c|l|l|l|l|l|r|}
\hline Item & P. diamor & P. eryngii & P. sajor-caju & P. citrinopileatus & Autoclaved straw (control) & SEM & P value \\
\hline Leu $^{*}$ & $16.77^{\mathrm{a}}$ & $14.19^{\mathrm{b}}$ & $16.89^{\mathrm{a}}$ & $17.47^{\mathrm{a}}$ & $11.31^{\mathrm{c}}$ & 0.478 & $<0.001$ \\
\hline Lys $^{\star}$ & $14.82^{\mathrm{ab}}$ & $12.32^{\mathrm{b}}$ & $13.58^{\mathrm{bc}}$ & $15.78^{\mathrm{a}}$ & $7.37^{\mathrm{c}}$ & 0.44 & $<0.001$ \\
\hline Met $^{\star}$ & $0.87^{\mathrm{b}}$ & $1.77^{\mathrm{ab}}$ & $2.63^{\mathrm{a}}$ & $1.12^{\mathrm{b}}$ & $1.95^{\mathrm{ab}}$ & 0.422 & 0.089 \\
\hline Phe $^{\star}$ & $9.84^{\mathrm{a}}$ & $8.57^{\mathrm{b}}$ & $9.93^{\mathrm{a}}$ & $10.02^{\mathrm{a}}$ & $6.57^{\mathrm{c}}$ & 0.37 & $<0.001$ \\
\hline Thr $^{*}$ & $12.17^{\mathrm{ab}}$ & $10.62^{\mathrm{bc}}$ & $12.71^{\mathrm{a}}$ & $12.62^{\mathrm{a}}$ & $8.96^{\mathrm{c}}$ & 0.549 & 0.003 \\
\hline Val $^{*}$ & $14.96^{\mathrm{ab}}$ & $13.33^{\mathrm{b}}$ & $16.62^{\mathrm{a}}$ & $14.97^{\mathrm{ab}}$ & $10.49^{\mathrm{c}}$ & 0.831 & 0.004 \\
\hline Ala & $20.66^{\mathrm{a}}$ & $18.37^{\mathrm{a}}$ & $20.1^{\mathrm{a}}$ & $21.3^{\mathrm{a}}$ & $18.56^{\mathrm{a}}$ & 1.55 & 0.615 \\
\hline Arg & $16.77^{\mathrm{b}}$ & $20.44^{\mathrm{a}}$ & $18.07^{\mathrm{ab}}$ & $19.54^{\mathrm{b}}$ & $5.33^{\mathrm{c}}$ & 0.92 & $<0.001$ \\
\hline Asp & $24.96^{\mathrm{a}}$ & $21.55^{\mathrm{b}}$ & $26.5^{\mathrm{a}}$ & $26.57^{\mathrm{a}}$ & $14.42^{\mathrm{c}}$ & 0.849 & $<.001$ \\
\hline Cys & $6.03^{\mathrm{a}}$ & $5.7^{\mathrm{a}}$ & $5.96^{\mathrm{a}}$ & $5.8^{\mathrm{a}}$ & $1.92^{\mathrm{b}}$ & 0.409 & $<0.001$ \\
\hline Glu & $27.98^{\mathrm{a}}$ & $29.2^{\mathrm{a}}$ & $30.82^{\mathrm{a}}$ & $27.98^{\mathrm{a}}$ & $22.99^{\mathrm{b}}$ & 0.07 & 0.005 \\
\hline Gly & $13.72^{\mathrm{ab}}$ & $12.34^{\mathrm{b}}$ & $13.8^{\mathrm{b}}$ & $14.26^{\mathrm{a}}$ & $9.27^{\mathrm{c}}$ & 0.38 & 0.001 \\
\hline His & $4.62^{\mathrm{a}}$ & $4.22^{\mathrm{a}}$ & $4.31^{\mathrm{a}}$ & $4.24^{\mathrm{a}}$ & $1.89^{\mathrm{b}}$ & 0.386 & $<0.001$ \\
\hline Ile & $10.68^{\mathrm{a}}$ & $9.04^{\mathrm{b}}$ & $10.86^{\mathrm{a}}$ & $11.03^{\mathrm{a}}$ & $7.08^{\mathrm{c}}$ & 0.508 & $<0.001$ \\
\hline Ser & $11.63^{\mathrm{a}}$ & $10.41^{\mathrm{a}}$ & $11.8^{\mathrm{a}}$ & $12.01^{\mathrm{a}}$ & $7.43^{\mathrm{b}}$ & 0.29 & 0.288 \\
\hline Tyr & $2.79^{\mathrm{a}}$ & $1.97^{\mathrm{a}}$ & $2.41^{\mathrm{a}}$ & $2.84^{\mathrm{a}}$ & $2.56^{\mathrm{a}}$ & & \\
\hline
\end{tabular}

Table 3. Amino acid composition ( $\mathrm{mg} / \mathrm{g}$ ) of corn stover after 21 days of incubation with various white rot fungi (Pleurotus sp.) or control. ${ }^{\star}$ Means essential amino acid. SEM: standard error of mean. ${ }^{\mathrm{a}-\mathrm{c}}$ Within a row, means without a common superscript differed $(P<0.001)$.

\begin{tabular}{|l|l|l|l|l|l|l|l|}
\hline Fungi/sample & P. diamor & P. eryngii & P. sajor-caju & P. citrinopileatus & Autoclaved straw (control) & SEM & $P$ value \\
\hline B1 (thiamine) & $1.64^{\mathrm{a}}$ & $0.61^{\mathrm{c}}$ & $1.55^{\mathrm{a}}$ & $0.5^{\mathrm{c}}$ & $0.85^{\mathrm{b}}$ & 0.076 & $<0.001$ \\
\hline B2 (riboflavin) & $0.57^{\mathrm{b}}$ & $0.57^{\mathrm{b}}$ & $0.28^{\mathrm{c}}$ & $0.29^{\mathrm{c}}$ & $0.92^{\mathrm{a}}$ & 0.049 & $<0.001$ \\
\hline B6 (pyridoxine) & $0.97^{\mathrm{b}}$ & $0.46^{\mathrm{c}}$ & $1.32^{\mathrm{a}}$ & $1.02^{\mathrm{b}}$ & $0.97^{\mathrm{b}}$ & 0.074 & $<0.001$ \\
\hline Folic acid & $27.25^{\mathrm{d}}$ & $250.03^{\mathrm{b}}$ & $327.41^{\mathrm{a}}$ & $61.37^{\mathrm{c}}$ & $0^{\mathrm{e}}$ & 1.92 & $<0.001$ \\
\hline Niacin & $31.28^{\mathrm{a}}$ & $22.53^{\mathrm{c}}$ & $24.76^{\mathrm{b}}$ & $18.05^{\mathrm{d}}$ & $0.025^{\mathrm{e}}$ & 0.257 & $<0.001$ \\
\hline VC & $19.03^{\mathrm{c}}$ & $22.08^{\mathrm{b}}$ & $24.91^{\mathrm{a}}$ & $0^{\mathrm{d}}$ & $0^{\mathrm{d}}$ & 0.226 & $<0.001$ \\
\hline
\end{tabular}

Table 4. Vitamin composition ( $\mathrm{mg} / \mathrm{kg}$ ) of corn stover after 21 days of incubation with various white rot fungi (Pleurotus sp.) or control. SEM: standard error of mean. ${ }^{\mathrm{a}-\mathrm{d}}$ Within a row, means without a common superscript differed $(P<0.001)$.

Met., Incubation of CS with sajor-caju and citrinopileatus resulted in the largest increases in essential amino acids. Maximum increases in Thr, Val and Met occurred in CS incubated with sajor-caju, wherereas citrinopileatus maximized Try, Phe, Leu and Lys. Regarding non-essential amino acids, diamor maximized cysteine (Cys) and histidine (His), whereas eryngii maximized arginine (Arg) and Glu was maximized by sajor-caju. Maximum of Ala, Asp, Gly, Ile, Ser and Tyr were increased by citrinopileatus incubation of CS, but Ala and Tyr were not significantly different compared to other treatment groups.

Vitamins. After 21 days of fermentation, there were significant differences among fungi in content of thiamine, riboflavin, pyridoxine, folic acid, niacin and vitamin C (Table 4). Compared to the control group, thiamine (B1) contents of diamor and sajor-caju treatment groups were higher, whereas eryngii and citrinopoleatus were lower. Thiamine was highest in the diamor group, but lowest in the citrinopoleatus group. Incubation with sajorcaju resulted in the greatest increase $(P<0.001)$ of pyridoxine $(\mathrm{B} 6)$, whereas eryngii had the least. Incubation with sajor-caju had the highest $(P<0.001)$ folic acid, whereas this vitamin was not detected after incubation with citrinopileatus or in autoclaved straw. All four white rot-fungi increased $(P<0.001)$ niacin contents of CS, whereas it was highest with diamor $(P<0.001)$. All treatments increased $(P<0.001)$ vitamin $\mathrm{C}$, except for citrinopileatus. Incubation of substrates with sajor-caju maximized vitamin $\mathrm{C}$ content.

\section{Discussion}

Changes in chemical composition of crop residues induced by fungi have been reported ${ }^{13,14}$. Growth of fungal mycelium was supported by degradation of lignocelluloses, increasing total protein content in the fermentation substrate and improving its nutrition quality. Similarly, in another report, $P$. diamor increased CP more than other fungi ${ }^{12}$. Differences among fungi in protein content after fermentation was related to the increase of fungal biomass. Furthermore, P. sajor-caju had a strong ability to degrade ADL. Lignin degradation of straw was positively correlated with IVD ${ }^{15}$. Thus, IVD was increased during solid state fermentation of agricultural residues by P. sajor-caju, similar to the results of this experiment. Therefore, we presumed P. sajor-caju had higher 


\begin{tabular}{|l|l|l|l|l|l|}
\hline Item & P. sajor-caju & P. citrinopileatus & Soybean meal & Wheat bran & Maize meal \\
\hline Leu & 16.89 & 17.47 & 27.54 & 9.44 & 9.35 \\
\hline Lys & 13.58 & 15.78 & 17.96 & 6.08 & 2.44 \\
\hline Phe & 9.93 & 10.02 & 19.45 & 6.71 & 3.88 \\
\hline Thr & 12.71 & 12.62 & 14.27 & 4.99 & 2.45 \\
\hline Val & 16.62 & 14.97 & 17.06 & 7.67 & 4.08 \\
\hline Sulfur-containing amino acids & 8.59 & 6.92 & 8.88 & 4.22 & 3.57 \\
\hline
\end{tabular}

Table 5. Content $(\mathrm{mg} / \mathrm{kg})$ of essential amino acids in corn stover after 21 days of incubation with two white rot fungi (P. or P. citrinopileatus) compared to common feeds.

selectivity to lignin degradation compared to cellulose and hemicellulose. In addition, digestibility is also related to fermentation time and constituents, concentration and structures of various plant cell wall polymers ${ }^{16}$.

Differences among substrates in their biological and chemical properties greatly affects nutritional value of the fermentation substrate. Biodelignification of wheat straw by solid state fermentation with white-rot fungi has been reported ${ }^{17,18}$. However, there are limited data regarding chemical composition of CS treated with white-rot fungi. In general, most substrate studies have used locally available agriculture wastes. In China, much of the CS is burned or disposed of in the field. Since not much CS is used for animal feed, it was chosen as a fermentation substrate for this study. To reduce fermentation time, we used liquid spawn fermentation of CS to increase protein content, reduce organic matter losses and shorten fermentation interval to produce feed suitable for ruminants. Nutritional values of substrates were directly associated with duration of incubation ${ }^{19}$, with reductions in lignin content and increases in CP content. It is noteworthy that reductions in cellulose and hemicellulose that occurred in the present study are not essential to enhance feed value for ruminants, as these livestock have the ability to degrade and utilize these substances.

It is well known that essential amino acids must be ingested from the diet and therefore must be considered in diet formulation. Analyzing amino acid composition of feedstuffs ensures that nutritional needs are $\mathrm{met}^{20}$ and supplementing essential amino acids may increase efficiency of animal production and enable low-cost ration formulation ${ }^{18}$. In this experiment, fermentation substrate had high concentrations (increased by 1.25-2.14 times compared to the control) of essential amino acids. Similar to the present observation, the amino acids profile of paddy straw was improved by less than a factor of two by incubation with Crinipellis sp. RCK-1 for 5 days at $30 \pm 2{ }^{\circ} \mathrm{C}^{21}$. Remarkably, exposure of paddy straw to Pleurotus ostreatus for 20 days improved amino acid content by as much as 15 times $^{22}$, much higher than the results of present study. Differences among studies are dependent on fungal species, fermentation substrate and fermentation time, as well as control component.

In comparisons of fungal fermentation of straw and alfalfa and orchardgrass ${ }^{23}$ amino acid contents of the straw were highest, highlighting potential to replace roughage as protein source for ruminants, especially where feed resources are limited In the present study, content of essential amino acids was higher in the fermentation substrate of sajor-caju and citrinopileatus after 21 days. The content of essential amino acids in the CS fermented by sajor-caju and citrinopileatus were compared to common feed material (Table 5). Although five essential amino acids in the fermentation substrate were lower than insoybean meal, they were 1.87-6.46 times higher than in wheat bran and maize meal. Therefore, fermented CS is valuable as a source of amino acids.

The Plearotus spp. are not only rich in essential amino acids, but also in vitamins ${ }^{24}$. Vitamins have important functions in animals, including essential metabolism ${ }^{25}$. It is noteworthy that the vitamin content after fermentation varies widely among fungal species ${ }^{26}$. It is interesting that riboflavin (B2) contents were $43.49-69.56 \%$ than lower than the control group in this experiment, apparently due to utilization by fungi. However, B1 content was increased, particularly by sajor-caju. Dietary requirements for many vitamins in ruminants are poorly defined. It has long been believed that the amount of B vitamins synthesized by rumen microorganisms can meet the nutritional requirements of animals. For adult ruminants, the sources of vitamin B are mainly from the synthesis of rumen microorganisms, so that supplementation of vitamin B are not required in the ruminant diet under normal circumstances. However, the $\mathrm{NRC}^{27}$ recommends that milk replacers for calves should include B1, B2, B6, niacin and folic acid at $6.5 \mathrm{mg} / \mathrm{kg} \mathrm{DM}, 6.5 \mathrm{mg} / \mathrm{kg} \mathrm{DM}, 0.1 \mathrm{mg} / \mathrm{kg} \mathrm{DM}, 10 \mathrm{mg} / \mathrm{kg}$ DM and $0.5 \mathrm{mg} / \mathrm{kg} \mathrm{DM}$, respectively. Some studies have shown that vitamin B supplements in the diet have many benefits for ruminants. For example, B vitamins stimulate cellulose bacteria in the rumen and they improve the digestibility of cellulose during in vitro fermentation ${ }^{28}$. Although daily niacin supplementation increased milk protein for cows in early lactation, it is not normally used in the beef industry ${ }^{29}$. Folic acid deficiency causes megablastic anemia and affects fetal development during pregnancy ${ }^{30}$. Accordingly, supplementing B vitamins in ruminant diet is related to animal species, diet and animal production stage. Vitamin $\mathrm{C}$ is an indispensable antioxidant component of animal feed, with important roles in animal health and immune function ${ }^{31}$. Dietary supplementation with vitamin C increases the concentration of vitamin C in skeletal muscle ${ }^{32}$. This will be promote stability of oxymyoglobin and lipid, which results in maintaining meat quality. Vitamin $\mathrm{C}$ supplementation in ruminants can have beneficial effects, especially under conditions of environmental stress. Furthermore, vitamin C supplementation in sheep can effectively relieve the stress of water shortage ${ }^{33}$. Additionally, vitamin C supplementation improved the tenderness of the beef longissimus dorsi and the fatty acid profile of meat products ${ }^{34}$. 


\section{Conclusions}

These four white rot fungi had high selectivity for lignin and increased CP content and IVD. In detail, eryngii fungi had the lowest reduction in dry matter during 21 days of incubation, whereas eryngii and sajor-caju fungi maximized lignin degradation and retention of cellulose, thereby improving rumen fermentability. In addition, incubation of substrates with these fungi improved contents of specific amino acids and vitamins. Therefore, these fungi have potential to improve the nutritional value of CS as a ruminant feed, with $P$. eryngii and $P$. sajorcaju yielding the best outcomes.

Received: 17 February 2021; Accepted: 7 May 2021

Published online: 07 June 2021

\section{References}

1. Shrivastava, B. et al. White-rot fungal conversion of wheat straw to energy rich cattle feed. Biodegradation 22, 823-831 (2011).

2. Cone, J. W., Baars, J. J. P., Sonnenberg, A. S. M. \& Hendriks, W. H. Fungal strain and incubation period affect chemical composition and nutrient availability of wheat straw for rumen fermentation. Bioresour. Technol. 111, 336-342 (2012).

3. Zhao, L. et al. Improving ruminal degradability and energetic values of bamboo shoot shell using chemical treatments. Anim. Sci. J. 87, 896-903 (2016).

4. García-Torreiro, M., López-Abelairas, M., Lu-Chau, T. A. \& Lema, J. M. Fungal pretreatment of agricultural residues for bioethanol production. Ind. Crops Prod. 89, 486-492 (2016).

5. Mukherjee, R. \& Nandi, B. Improvement of in vitro digestibility through biological treatment of water hyacinth biomass by two Pleurotus species. Int. Biodeter. Biodegr. 53, 7-12 (2004).

6. Zheng, Y. G., Chen, X. L. \& Wang, Z. Microbial biomass production from rice straw hydrolysate in airlift bioreactors. J. Biotechnol. 118, 413-420 (2005).

7. Akin, D. E. et al. Biological delignification of plant components by the white rot fungi Ceriporiopsis subvermispora and Cyathus stercoreus. Anim. Feed Sci. Technol. 63, 305-321 (1996)

8. Goering, H. K. \& Van Soest, P. J. Forage fiber analyses: Apparatus, reagents, procedures, and some applications. Usda. Agr. Handb. 379, 1-20 (1970)

9. Van Soest, P. J., Robertson, J. B. \& Lewis, B. A. Methods for dietary fiber, neutral detergent fiber and nonstarch polysacchaids in relation to animal nutrition. J. Dairy Sci. 74, 3583-3598 (1991).

10. Akhter, S., Owen, E., Theodorou, M. K., Butler, E. A. \& Minson, D. J. Bovine faeces as a source of micro-organisms for the in vitro digestibility assay of forages. Grass Forage Sci. 54, 219-226 (1999).

11. Sharma, R. K. \& Arora, D. S. Changes in biochemical constituents of paddy straw during degradation by white rot fungi and its impact on in vitro digestibility. J. Appl. Microbiol. 109, 679-686 (2010).

12. Mdachi, S. J. M., Nkunya, M. H. H., Nyigo, V. A. \& Urasa, I. T. Amino acid composition of some Tanzanian wild mushrooms. Food Chem. 86, 179-182 (2004).

13. Jafari, M. A., Nikkhah, A., Sadeghi, A. A. \& Chamani, M. The effect of Pleurotus spp. fungi on chemical composition and in vitro digestibility of rice straw. Pak. J. Biol. Sci. 10, 2460-2464 (2007).

14. Mikiashvili, N., Wasser, S. P., Nevo, E. \& Elisashvili, V. Effects of carbon and nitrogen sources on Pleurotus ostreatus ligninolytic enzyme activity. World J. Microb. Biot. 22, 999-1002 (2006).

15. Wahyono, T. et al. Nutrient value and digestibility variation of five rice straw cultivars in Indonesia as ruminant roughage. Adv. Anim. Vet. Sci. 9(1), 73-81 (2021).

16. Arora, D. S., Sharma, R. K. \& Chandra, P. Biodelignification of wheat straw and its effect on in vitro digestibility and antioxidant properties. Int. Biodeter. Biodegr. 65, 352-358 (2011).

17. Huang, H. et al. Effect of biodelignification of rice straw on humification and humus quality by Phanerochaete chrysosporium and Streptomyces badius. Int. Biodeter. Biodegr. 61, 331-336 (2008).

18. Turkoglu, A., Duru, M. E., Mercan, N., Kivrak, I. \& Gezer, K. Antioxidant and antimicrobial activities of Laetiporus sulphureus (Bull.) Murrill. Food Chem. 101, 267-273 (2007).

19. Sharma, R. K. \& Arora, D. S. Fungal degradation of lignocellulosic residues: An aspect of improved nutritive quality. Crit. Rev. Microbiol. 41, 52-60 (2015).

20. Rotz, C. A. Management to reduce nitrogen losses in animal production. J. Anim. Sci. 82, 119-137 (2004).

21. Shrivastava, B., Jain, K. K., Kalra, A. \& Kuhad, R. C. Bioprocessing of wheat straw into nutritionally rich and digested cattle feed. Sci. Rep. U.K. 4, 6360 (2014).

22. Chalamcherla, V. L. \& Muvva, V. L. Amino acids profile of the lignocellulosic feed treated with cellulase-free lignolytic mutants of Pleurotus ostreatus. Bioresource 5, 259-267 (2010).

23. Balde, A. T., Vandersall, J. H., Erdman, R. A., Reeves, J. B. \& Glenn, B. P. Effect of stage of maturity of alfalfa and orchardgrass on in situ dry matter and crude protein degradability and amino acid composition. Anim. Feed Sci. Technol. 44, 29-43 (1993).

24. Khan, M. A. \& Tania, M. Nutritional and medicinal importance of Pleurotus mushrooms: An overview. Food. Rev. Int. 28, 313-329 (2012).

25. Moll, R. \& Davis, B. Iron, vitamin B12 and folate. Medicine 45, 198-203 (2017).

26. Bernaś, E. \& Jaworska, G. Vitamins profile as an indicator of the quality of frozen Agaricus bisporus mushrooms. J. Food Compos. Anal. 49, 1-8 (2016).

27. NRC: Nutrient Requirements of Dairy Cattle. National Research Council, Washington DC (2001).

28. Scott, H. W. \& Dehority, B. A. Vitamin requirements of several cellulolytic rumen bacteria. J. Bacteriol. 89, 1169-1175 (1965).

29. Schwab, E. C., Caraviello, D. Z. \& Shaver, R. D. A meta-analysis of lactation responses to supplemental dietary niacin in dairy cows. Prof. Anim. Sci. 21, 239-247 (2005).

30. Sencer, E. Beslenme ve Diyet. Istanbul Universitesi Bayda yayinlari Vakfi, Istanbul: Bayda yayinlari. pp. 102-215 (1983).

31. Roeder, R. A. Beyond deficiency: New views of vitamins in ruminant nutrition and health: An overview. J. Nutr. 125, 1790-1791 (1995).

32. Schaefer, D. M., Liu, Q., Faustman, C. \& Yin, M. C. Supranutritional administration of vitamins E and C improves oxidative stability of beef. J. Nutr. 125, 1792S-1798S (1995).

33. Ghanem, A. M., Jaber, L. S., Said, M. A., Barbour, E. K. \& Hamadeh, S. K. Physiological and chemical responses in water-deprived Awassi ewes treated with vitamin C. J. Arid Environ. 72, 1-149 (2008).

34. Pogge, D. J., Lonergan, S. M. \& Hansen, S. L. Supplemental Vitamin C alleviates the negative effect of high sulfur on meat quality. Anim. Ind. Rep. 659, 17 (2013). 


\section{Acknowledgements}

This work was financially supported by the Natural Science Foundation of Inner Mongolia autonomous region, China (Grant Nos. 2019BS03023 and 2018LH03011), the PhD research startup foundation of Inner Mongolia University for Nationalities (KYQD18053). Scientific Research Project of Inner Mongolia University for nationalities (NMDYB20032).

\section{Author contributions}

C.G. designed the experiments. Y.W. and L.L. preformed the experiment. Y.W. analyzed the data and wrote the main manuscript. H.Z. and Y.L. critically revised the content. C.G. and Y.L. improved the language of the manuscript. All Authors have read and approved the manuscript.

\section{Competing interests}

The authors declare no competing interests.

\section{Additional information}

Correspondence and requests for materials should be addressed to Y.L. or C.G.

Reprints and permissions information is available at www.nature.com/reprints.

Publisher's note Springer Nature remains neutral with regard to jurisdictional claims in published maps and institutional affiliations.

(c) (i) Open Access This article is licensed under a Creative Commons Attribution 4.0 International cc) License, which permits use, sharing, adaptation, distribution and reproduction in any medium or format, as long as you give appropriate credit to the original author(s) and the source, provide a link to the Creative Commons licence, and indicate if changes were made. The images or other third party material in this article are included in the article's Creative Commons licence, unless indicated otherwise in a credit line to the material. If material is not included in the article's Creative Commons licence and your intended use is not permitted by statutory regulation or exceeds the permitted use, you will need to obtain permission directly from the copyright holder. To view a copy of this licence, visit http://creativecommons.org/licenses/by/4.0/.

(C) The Author(s) 2021 